\title{
PEMODELAN ARSITEKTUR SISTEM PENGELOLAAN SUKU CADANG PESAWAT MENGGUNAKAN TOGAF ADM
}

\author{
Yessy Aviantary Putri $^{1}$, Yupie Kusumawati ${ }^{2}$ \\ ${ }^{1,2}$ Jurusan Sistem Informasi Fakultas Ilmu Komputer Universitas Dian Nuswantoro Semarang \\ Jl. Imam Bonjol No.207, Semarang, 50131 \\ ${ }^{1} 112201705862 @$ mhs.dinus.ac.id \\ 2yupie@dsn.dinus.ac.id
}

\begin{abstract}
Abstrak - Pengelolaan suku cadang pesawat merupakan hal utama yang penting dilakukan perusahaan untuk menyediakan komponen atau alat-alat yang akan di produksi menjadi sebuah mesin pesawat, dan kebutuhan produksi lainnya dengan memastikan kondisi dan kualitas suku cadang terkualifikasi dengan baik. PT. Jefco Aero Teknologi merupakan perusahaan yang beroperasi di sektor perawatan pesawat atau bisa disebut dengan MRO (Maintenance, Repair and Overhaul) pesawat. Namun, dalam pelaksanaan pengelolaan suku cadang di PT. Jefco Aero Teknologi masih memiliki permasalahan seperti proses bisnis yang tidak saling terintegrasi, pengolahan data supplier yang belum terstruktur hingga masih terdapat kesalahan dalam pengelolaan stok suku cadang. Dalam menangani hal tersebut penulis mengusulkan untuk melakukan pemodelan arsitektur menggunakan TOGAF ADM yang mencakup arsitektur bisnis, arsitektur sistem informasi, dan arsitektur teknologi dengan hasil penelitian berupa blueprint TI sebagai pedoman untuk mempercepat kinerja para pegawai, dan mampu memberikan perubahan proses bisnis secara efektif.
\end{abstract}

Kata kunci : TOGAF ADM; Enterprise Architecture; Blueprint TI; Sistem Pengelolaan Suku Cadang Pesawat

\section{PENDAhuluan}

Pengelolaan suku cadang pesawat merupakan hal pertama yang penting dilakukan perusahaan untuk menyediakan komponen atau alat-alat yang akan di produksi menjadi sebuah mesin pesawat, dan kebutuhan produksi lainnya dengan memastikan kondisi dan kualitas suku cadang terkualifikasi dengan baik.

PT. Jefco Aero Teknologi merupakan perusahaan yang beroperasi di sektor perawatan pesawat atau bisa disebut dengan MRO (Maintenance, Repair dan Overhaul) pesawat. Namun, PT. Jefco Aero Teknologi memiliki beberapa permasalahan dalam pengelolaan suku cadang pesawat diantaranya masih terdapat proses bisnis yang terpecah-pecah atau tidak saling terintegrasi, pengelolaan data supplier yang masih belum terstruktur, belum adanya validasi dengan manager sebelum melakukan PO, dan masih sering terjadi kesalahan dalam mengelola stok masuk dan stok keluar pada penerimaan dan pengeluaran suku cadang. Sehingga aspek arsitektur bisnis, arsitektur sistem informasi, dan arsitektur teknologi. Berkaitan dengan hal tersebut, diperlukannya arsitektur enterprise. Arsitektur enterprise merupakan sebuah perancangan sistem pada perusahaan untuk mendukung keperluan bisnis dan teknologi agar terwujudnya visi, misi dan hasil [1].

Terdapat beberapa penelitian yang berkaitan dengan penelitian ini, antara lain penelitian pada tahun 2015 dengan objek penelitian di PT. Bali Double C yang menggunakan framework TOGAF ADM untuk menghasilkan sebuah blueprint yang mengintegrasikan arsitektur bisnis, arsitektur aplikasi, arsitektur data, dan arsitektur teknologi yang dapat membantu PT. Bali Double C dalam membangun SI/TI untuk memenuhi kebutuhan bisnis [2]. Kemudian, terdapat penelitian pada tahun 2017 dengan objek penelitian di Universitas Dian Nuswantoro yang bertujuan untuk merancang sistem indeks kinerja dosen di Fakultas Ilmu Komputer dengan metode TOGAF ADM sehingga memberikan blueprint yang lebih terstruktur [3]. Penelitian yang dilakukan di Ibi Darmajaya Bandar Lampung pada tahun 2017 dengan tujuan untuk menghasilkan blueprint untuk mengintegrasikan pengadaan barang inventarisasi, pengelolaan dan perawatan sarana-prasarana [4]. Penelitian yang dilakukan di Marino Collection pada tahun 2018 yang bertujuan untuk meningkatkan strategi bisnis dengan menggunakan framework TOGAF ADM, dan menghasilkan blueprint yang sesuai dengan kebutuhan bisnis [5]. Penelitian 
terakhir yaitu penelitian pada PT. Gading Putra Samudra dengan tujuan untuk membangun EA dengan framework TOGAF ADM untuk menghasilkan blueprint sehingga aktivitas bisnis dapat terintegrasi [6].

Berdasarkan penelitian sebelumnya terdapat perbedaan dengan penelitian ini yaitu pada fokus permasalahan, dan objek penelitian. Sehingga, pada penelitian ini dilakukannya sebuah pemodelan arsitektur pada PT. Jefco Aero Teknologi dengan menggunakan TOGAF ADM dengan melihat kondisi yang terjadi yang belum memiliki blueprint TI, dan dibutuhkannya perbaikan dari beberapa proses bisnis pengelolaan suku cadang. Tidak hanya itu, TOGAF juga bersifat fleksibel, open source dan memiliki teknis arsitektur yang lengkap dalam EA [7]. Sehubungan hal tersebut, penelitian ini akan dihasilkan blueprint TI atau cetak biru berdasarkan arsitektur bisnis, arsitektur sistem informasi, dan arsitektur teknologi yang saling terintegrasi untuk PT. Jefco Aero Teknologi yang dijadikan sebuah pedoman khusus pada pengelolaan suku cadang pesawat yang bertujuan untuk mempercepat kinerja para pegawai dan memberikan perubahan pada proses bisnis sehingga aktivitas pada perusahaan mampu dijalankan secara efektif dan efisien.

Berdasarkan uraian latar belakang diatas didapatkan rumusan masalah sebagai berikut:

1. Bagaimana cara memodelkan arsitektur Enterprise Architecture untuk dapat membantu bagian General Affairs Staff, General Affairs Manager, Quality Assurance, Finance Staff, Finance Manager, dan Direktur Utama untuk mengelola suku cadang pesawat?

\section{Metodologi Penelitian}

1. Metode Penelitian

Adapun gambaran dari metode penelitian yang dilakukan melalui Gambar 1 berikut ini:

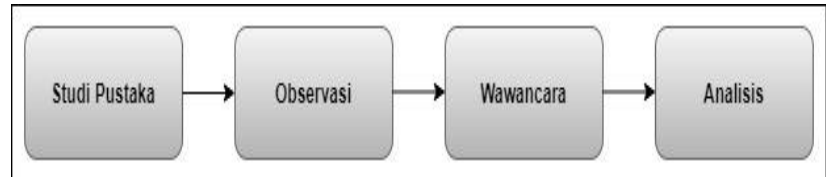

Gambar 1. Metode Penelitian

2. Metode Analisis

Metode analisis yang digunakan yaitu dengan framework The Open Group Architecture Method (TOGAF ADM). TOGAF merupakan suatu framework dari arsitektur enterprise yang digunakan sebagai sarana pengembangan arsitektur dalam organisasi atau perusahaan. Pada metode analisis yang digunakan pada penelitian ini menggunakan 6 (enam) fase dari TOGAF ADM diantaranya dimulai pada preliminary phase, requirement management, architecture vision, business architecture, information system architecture, dan technology architecture yang lebih menekankan pada pemodelan arsitektur enterprise yang sesuai pada Gambar 2 berikut ini

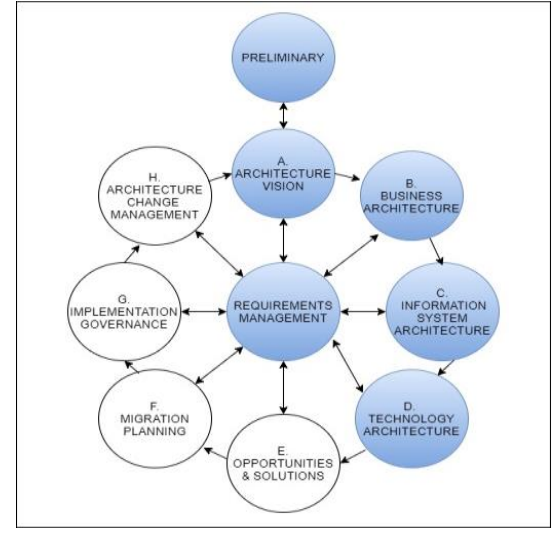

Gambar 2. Metode analisis TOGAF

\section{1) Preliminary Phase}

Pada fase ini menggambarkan mengenai tahapan awal untuk melakukan pemodelan arsitektur. Pada fase ini mengidentifikasi lingkup internal, menentukan framework yang digunakan, menentukan stakeholder serta menerapkan prinsip-prinsip arsitektur bisnis, arsitektur data, arsitektur sistem informasi.

\section{2) Requirement Phase}

Pada fase ini memastikan bahwa setiap proses bisnis pengelolaan suku cadang di PT. Jefco Aero Teknologi yang sedang berjalan teridentifikasi dengan benar guna memastikan untuk tahapan selanjutnya.

\section{3) Phase A : Architecture Vision}

Pada fase ini menggambarkan arsitektur mengenai visi berdasarkan pemodelan arsitektur di PT. Jefco Aero Teknologi yang akan mendukung visi dan misi sesuai dengan yang ditetapkan dan menggambarkan mengenai aktivitas dan struktur organisasi, dan akan mengusulkan struktur organisasi usulan untuk PT. Jefco Aero Teknologi.

4) Phase B : Business Architecture

Pada fase ini menggambarkan usulan proses bisnis untuk mencapai visi pada PT. Jefco Aero Teknologi di bagian pengelolaan data supplier, pengelolaan sertifikat resmi, pembuatan purchase order (PO), dan pengelolaan penerimaan dan pengeluaran suku cadang pesawat.

\section{5) Phase $C$ : Information System Architecture}

Pada fase ini menggambarkan arsitektur aplikasi dan arsitektur data berdasarkan arsitektur bisnis pada PT. Jefco Aero Teknologi untuk melengkapi kebutuhan perancangan arsitektur yang akan mendukung kegiatan utama dan kegiatan pendukung dan akan menghasilkan arsitektur aplikasi.

6) Phase D : Technology Architecture 
Pada fase ini menggambarkan mengenai rancangan arsitektur teknologi yang akan mendukung kegiatan proses bisnis pada PT. Jefco Aero Teknologi seperti merencanakan usulan konfigurasi jaringan teknologi.

\section{HASIL DAN PEMBAHASAN}

Pada bagian ini menghasilkan suatu pemodelan arsitektur enterprise yang tepat dengan kerangka kerja TOGAF ADM sebagai berikut :

\section{Preliminary Phase}

Pada tahap Preliminary Phase ini merupakan tahapan persiapan awal yang dilakukan untuk memodelkan arsitektur sehingga dapat terarahkan secara baik. Berikut ini terdapat prinsip-prinsip yang digunakan pada PT. Jefco Aero Teknologi :

TABEL I

PRINSIP-PRINSIP PERANCANGAN ENTERPRISE ARCHITECTURE

\begin{tabular}{|c|c|}
\hline No. & Prinsip \\
\hline 1. & Pembuatan keputusan \\
\hline & arsitektur yang harus \\
\hline & sesuai dengan visi dan \\
\hline & misi aktivitas, serta \\
\hline & proses bisnis yang \\
\hline & terdapat pada PT. Jefco \\
\hline & Aero Teknologi. \\
\hline
\end{tabular}

2. Arsitektur yang dirancang harus mendukung kesinambungan dari bisnis,

3. Pengelolaan arsitektur aplikasi suruh user friendly

\section{Tujuan}

a. Meningkatkan serta memudahkan dalam pengelolaan suku cadang pesawat.

b. Mendukung proses bisnis pengelolaan suku cadang pesawat di PT. Jefco Aero Teknologi

Meminimalisir gangguan pada sistem yang menghambat operasional bisnis.

\section{a. Membantu kerja} sama antar bagian General Affairs Staff, General Affairs Manager, Finance Staff, Finance Manager, Quality Assurance, dan Direktur Utama.

b. Meningkatkan kemampuan sharing

data dan sumber daya lain dalam pelayanan terhadap user.

c. Membantu proses pengelolaan suku cadang pesawat.

4. Data dan sistem informasi terlindungi agar tidak diakses oleh pihak-pihak yang tidak berwenang. a. Melindungi akses dari pihak yang tidak berwenang.

b. Mengatur stakeholder dalam pengelolaan data.

5. Arsitektur yang
dikembangkan harus
aman

a. Supaya tidak terjadi kebocoran data, dan terjamin kerahasiaan data.

b. Meminimalkan dampak dari bencana.

c. Mampu bertahan dari serangan virus, hacker, worm, dan lain sebagainya.

6. Perancangan aplikasi Memudahkan proses harus saling terintegrasi pengelolaan data dalam meningkatkan kualitas layanan aplikasi.

7. Data harus mudah Memudahkan data untuk diakses diakses secara bersamaan sehingga mempercepat kinerja PT. Jefco Aero Teknologi.

8. Independensi teknologi Dapat disesuaikan dan digunakan pada platform teknologi.

\section{Requirement Phase}

Pada fase Requirement Management bertujuan dalam menentukan kebutuhan seluruh proses pemodelan arsitektur untuk PT. Jefco Aero Teknologi dalam menganalisa proses bisnis yang sedang berjalan seperti dibawah ini :

1) Pengelolaan Data Supplier 


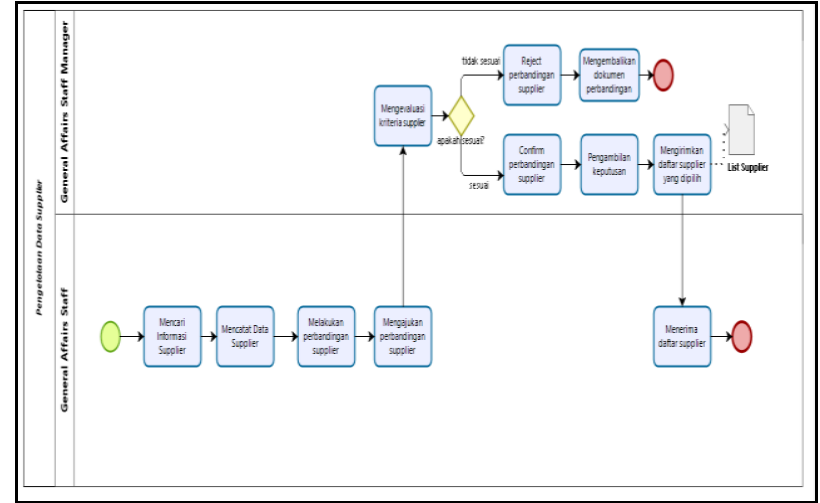

Gambar 3. BPMN Pengelolaan Data Supplier

2) Pengelolaan Sertifikat Resmi Suku Cadang

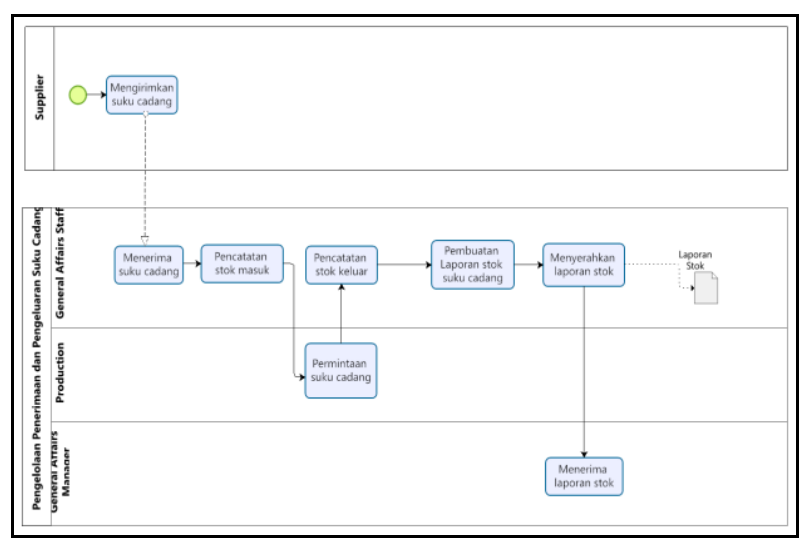

Gambar 4. BPMN Pengelolaan Sertifikat Resmi Suku Cadang

3) Pembuatan PO

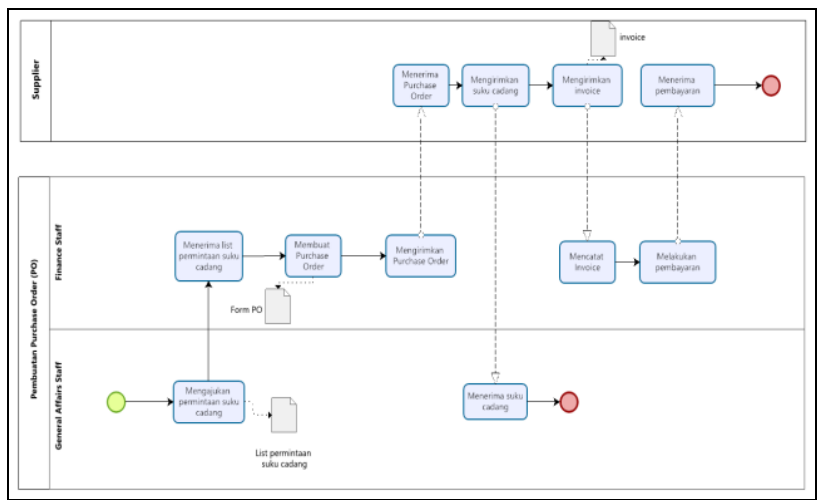

Gambar 5. BPMN Pembuatan PO

4) Penerimaan dan Pengeluaran Suku Cadang

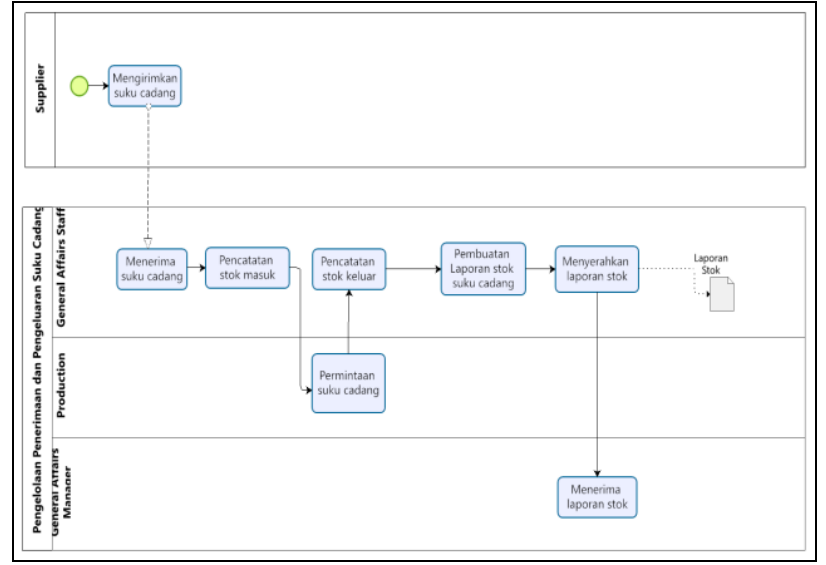

Gambar 6. BPMN Penerimaan dan Pengeluaran Suku Cadang

3. Phase A : Architecture Vision

Pada fase ini akan dilakukannya analisa, serta perancangan yang mencakup analisa bisnis, arsitektur sistem informasi, dan arsitektur teknologi. Terdapat analisa value chain PT. Jefco Aero Teknologi yang dikelompokkan berdasarkan aktivitas pendukung dan aktifitas utama diantaranya sebagai Gambar 7 berikut ini :

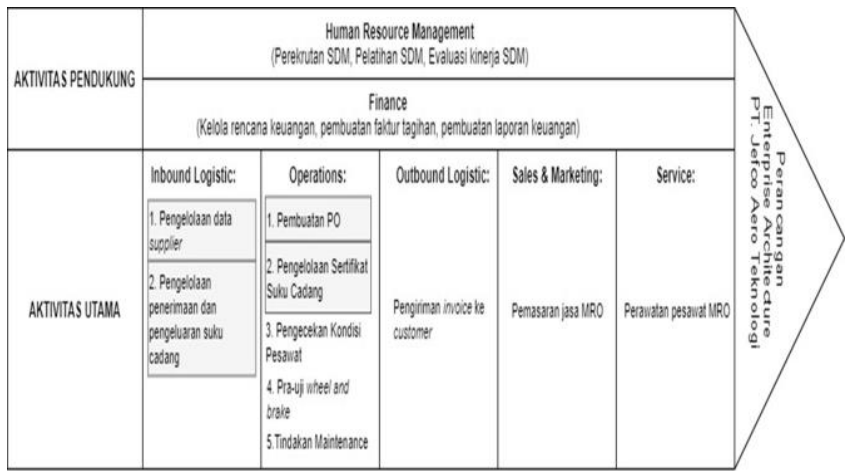

Gambar 7. Value Chain PT. Jefco Aero Teknologi

Pada Gambar 7 merupakan value chain yang berisikan aktivitas pendukung, dan aktivitas utama yang terdapat di PT. Jefco Aero Teknologi.

4. Phase B : Business Architecture

Fase ini bertujuan dalam mengusulkan beberapa proses bisnis yang mengalami perubahan dan perbaikan :

1) Usulan Proses Bisnis Pengelolaan Data Supplier 


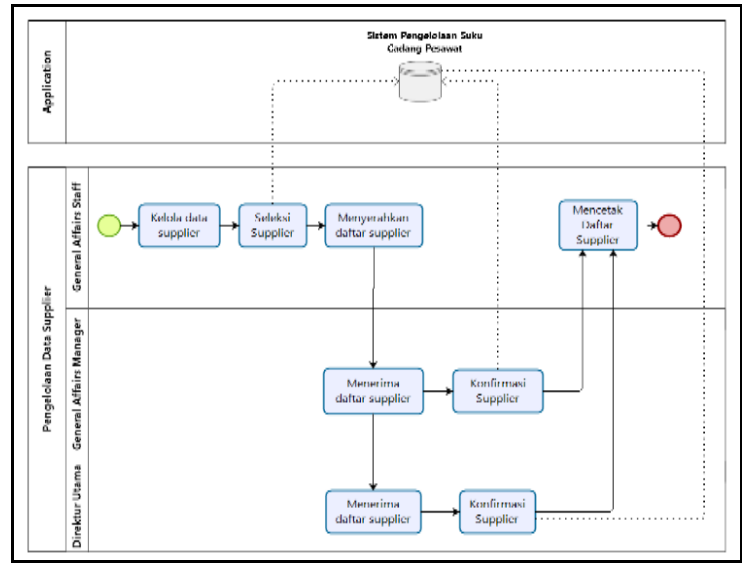

Gambar 8. Usulan BPMN Pengelolaan Data Supplier

Pada Gambar 8. merupakan usulan BPMN pengelolaan data supplier yang memiliki usulan dengan penambahan penentuan kriteria yang disepakati, apabila sesuai dengan kriteria maka akan masuk ke daftar supplier, serta terdapat permintaan validasi ke General Affairs Manager, dan direktur utama.

2) Usulan Proses Bisnis Pengelolaan Sertifikat Resmi

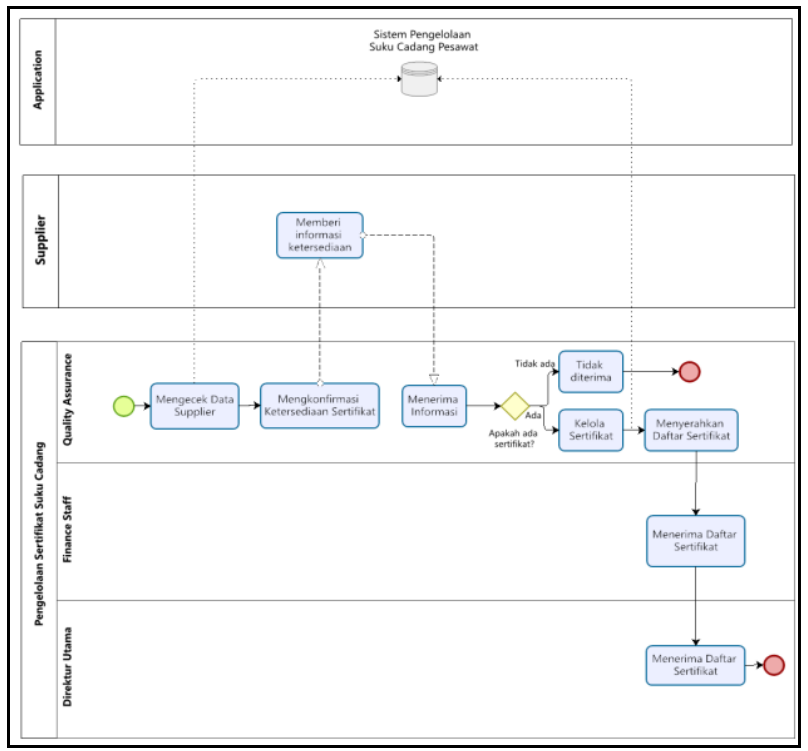

Gambar 9. Usulan BPMN Pengelolaan Sertifikat Resmi Suku Cadang

Pada Gambar 9. diatas merupakan usulan BPMN pada pengelolaan sertifikat resmi suku cadang yang terdapat usulan dalam perubahan aktor yakni Quality Assurance untuk memeriksa sertifikat resmi.

3) Usulan Proses Bisnis Pembuatan PO

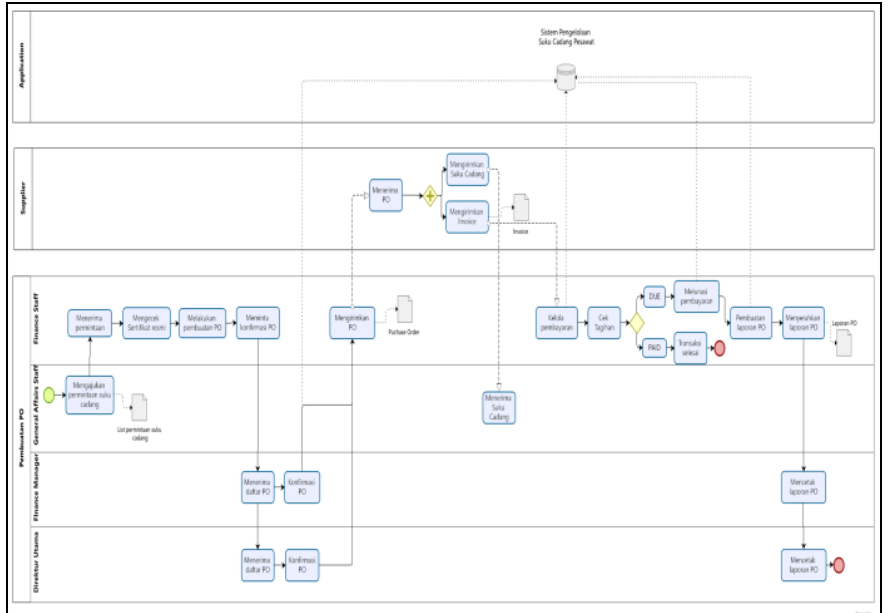

Gambar 10. Usulan BPMN Pembuatan PO

Pada Gambar 10. merupakan usulan BPMN dari pembuatan PO diantaranya Finance Staff dapat melakukan pengecekan sertifikat resmi, kemudian adanya konfirmasi PO sebelum pembuatan PO melalui finance manager, dan direktur utama, serta terdapat pengecekan tagihan seperti status tagihan "DUE" atau "PAID".

4) Usulan Proses Bisnis Penerimaan dan Pengeluaran Suku Cadang

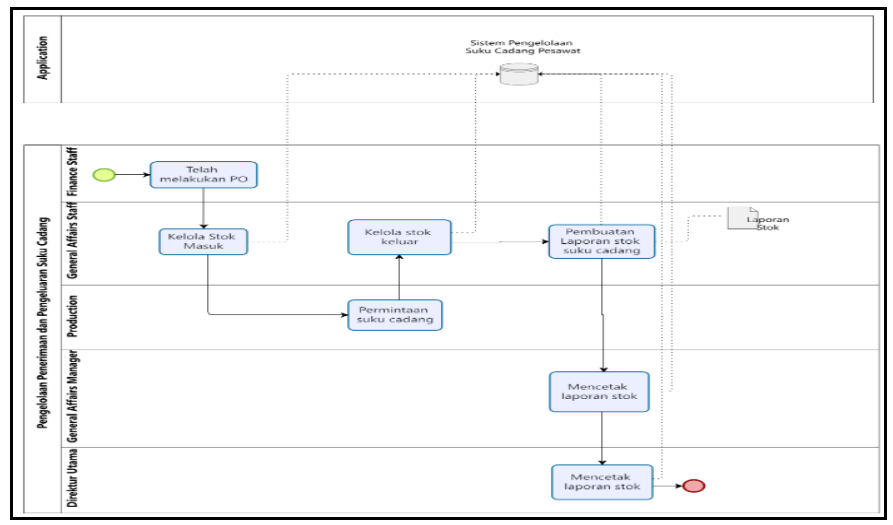

Gambar 11. Usulan BPMN Penerimaan dan Pengeluaran

Pada Gambar 11. merupakan usulan BPMN pada penerimaan dan pengeluaran suku cadang diantaranya terdapat perbedaan proses bisnis, yakni pengelolaan stok masuk berdasarkan PO yang telah dibuat oleh Finance Staff, dan pelaporan stok suku cadang yang dapat dicetak oleh General Affairs Staff Manager, dan direktur utama.

\section{Phase C : Information System Architecture}

Pada fase $\mathrm{C}$ ini berisikan use case diagram untuk memodelkan arsitektur aplikasi, dan class diagram untuk memodelkan arsitektur data yang menjadi suatu arsitektur sistem informasi : 
1) Arsitektur Aplikasi

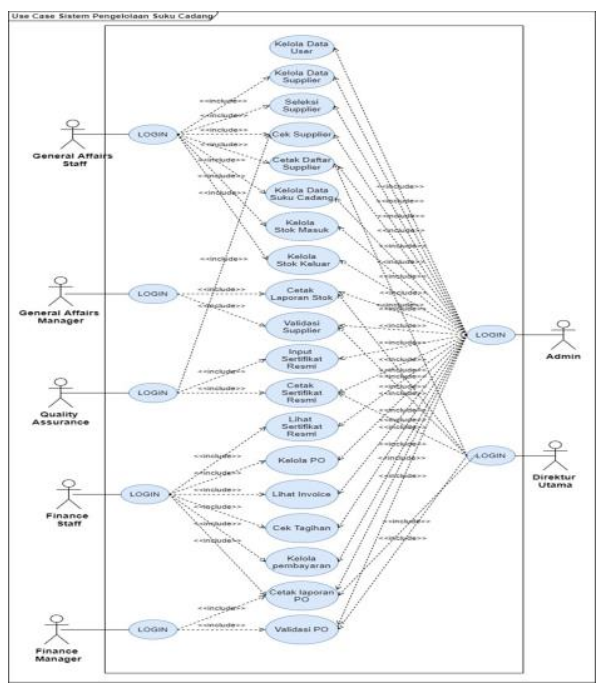

Gambar 12. Use Case Sistem Pengelolaan Suku Cadang Pesawat

2) Arsitektur Data

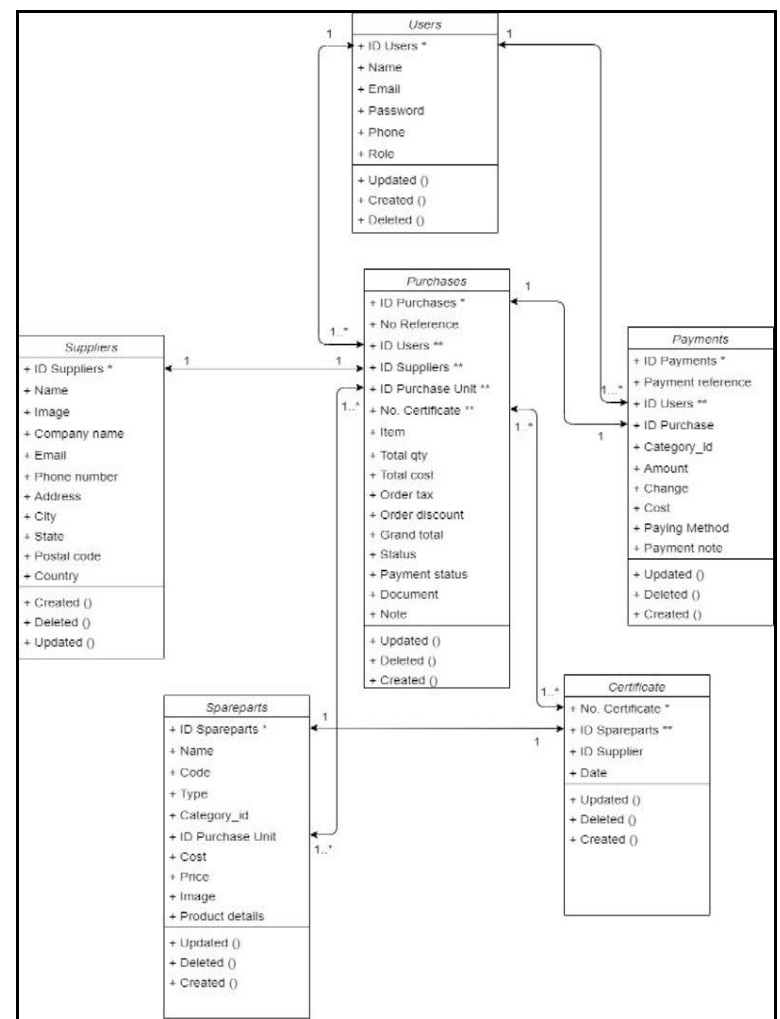

Gambar 13. Class Diagram Sistem Pengelolaan Suku Cadang Pesawat

\section{Phase D : Technology Architecture}

Pada fase ini arsitektur sistem informasi akan berjalan di atas arsitektur teknologi. Maka digambarkan infrastruktur jaringan melalui Gambar berikut ini :

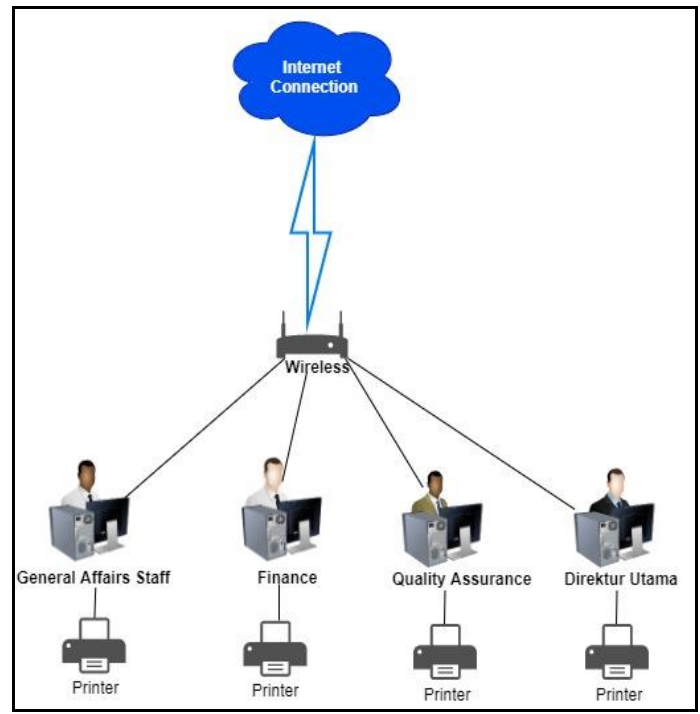

Gambar 14. Kondisi Jaringan saat ini

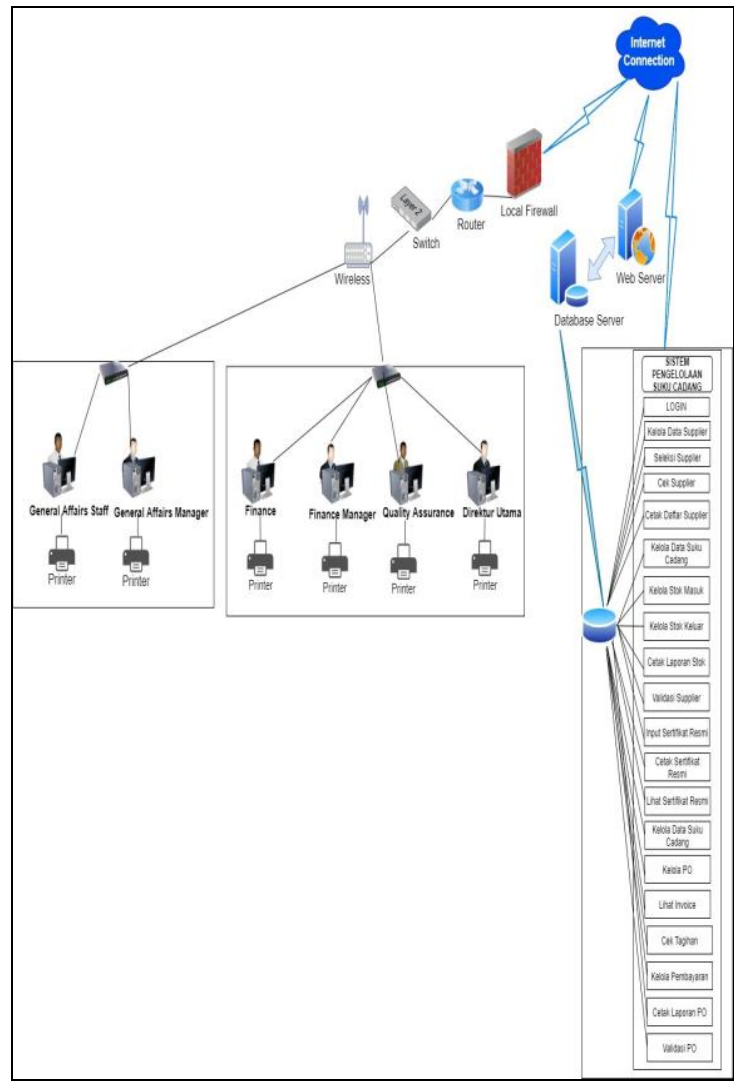

Gambar 15. Usulan Jaringan Teknologi

7. Pembuatan Blueprint 
Berdasarkan pemodelan arsitektur enterprise diatas yang terdiri dari arsitektur bisnis, arsitektur sistem informasi, dan arsitektur teknologi maka akan dihasilkan sebuah blueprint yang mengintegrasikan ketiga arsitektur tersebut dan mendokumentasikan sebagai pedoman pengembangan EA. Berikut ini merupakan Blueprint dari PT. Jefco Aero Teknologi :

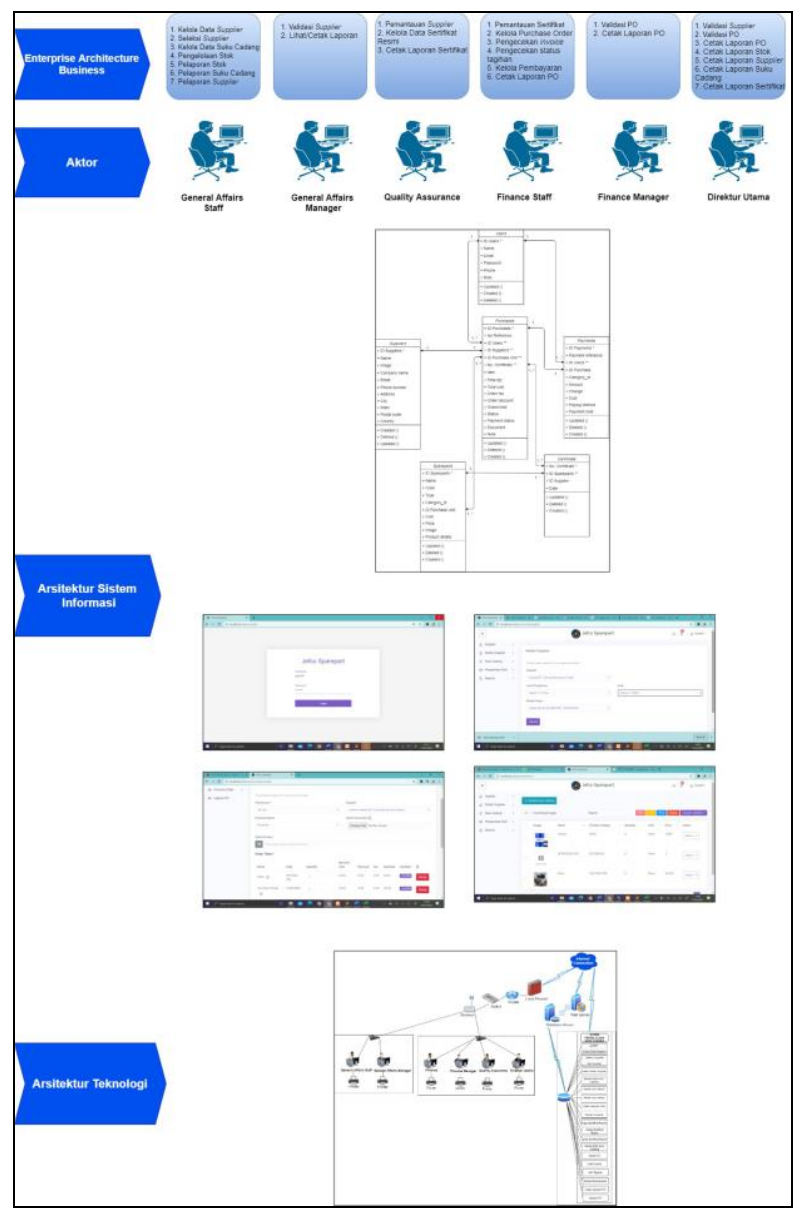

Gambar 16. Blueprint PT. Jefco Aero Teknologi

\section{KESIMPULAN}

Berdasarkan hasil yang diperoleh, maka didapatkan kesimpulan bahwa pada penelitian ini penulis melakukan pemodelan arsitektur enterprise pada PT. Jefco Aero Teknologi yang menghasilkan sebuah blueprint dengan mengintegrasikan arsitektur bisnis, arsitektur sistem informasi, dan arsitektur teknologi sehingga dapat mempercepat serta membantu proses pengelolaan data supplier, pengelolaan sertifikat resmi, pembuatan PO, serta pengelolaan penerimaan dan pengeluaran suku cadang, yang sesuai dan juga menghasilkan sistem pengelolaan suku cadang berbasis website yang akan menjadi sebuah usulan baru guna mendukung pengambilan keputusan yang dilakukan General Affairs Manager, Finance Manager, dan Direktur Utama menjadi lebih mudah, dan efektif.

\section{REFERENSI}

[1] N. Safitri and R. Pramudita, "Pengembangan Kerangka Kerja Arsitektur Enterprise," Bina Insa. ICT J., vol. 4, no. 1, pp. 73-82, 2017.

[2] T. Sulandari, "Perancangan enterprise architecture menggunakan togaf architecture development method (studi kasus PT. Bali Double C),” p. 238, 2015.

[3] I. G. Pertiwi and W. Shinta, "Perancangan Enterprise Arsitektur Sistem Indeks Kinerja Dosen Fakultas Ilmu Komputer di Universitas Dian Nuswantoro dengan Metode TOGAF ADM," vol. 21, pp. 0-1, 2017.

[4] M. Agarina, "Pemanfaatan Framework Togaf Untuk Perencanaan Sistem Informasi Manajemen Aset Dan Logistik Di Ibi Darmajaya Bandar Lampung (Studi Kasus : Ibi Darmajaya Bandar Lampung)," J. Inform. Darmajaya, vol. 15, no. 2, pp. 175-187, 2015, doi: 10.30873/ji.v15i2.599.

[5] S. Eviana, "Perancangan Enterprise Architecture Sistem Penjualan Dengan Metode TOGAF ADM Pada Marino Collection," vol. 6, No.1, pp. 106-113, 2018, [Online]. Available: http://ojs.stmikpringsewu.ac.id/index.php/procidingk msi/article/view/627/560.

[6] J. S. Antouw and J. F. Andry, "Perancangan Enterprise Architecture Pada PT. Gading Putra Samudra Menggunakan Framework TOGAF ADM," vol. 14, no. 2, pp. 71-80, 2020.

[7] Mukhfid, "Perencanaan Arsitektur Sistem Informasi Enterprise Koperasi Dengan TOGAF Framework," Unwir.Ac.Id, vol. VIII, no. 1, pp. 61-73, 2017. 